\title{
Relations between pig growth and regulatory mechanism of pancreas - facts and hypotheses
}

\author{
S.G. Pierzynowski', D. Kruszewska, S. Rengman, O. Fed'kiv, \\ M. Dąbek, A. Hotowy, E. Werpachowska and B.R. Weström
}

\author{
Department of Cell and Organism Biology, Lund University \\ Helgonavägen 3b, 22362 Lund, Sweden
}

\begin{abstract}
The aim of the mini review is to more precisely determine the relationship between exocrine pancreas function and the growth of young pigs. In order to do so, it is necessary to clarify the components, pathways and messengers involved in the CCK-dependent neuro-hormonal regulation of the exocrine pancreas in the growing pigs. These mechanisms are largely unknown, and the role of CCK has been questioned since CCK receptors on the enzyme producing acinar cells are lacking. Our hitherto obtained results have shown the importance of CCK for the pancreatic enzyme secretion and that in pigs CCK functions via CCK-B receptor-mediated entero(duodenal)-pancreatic reflex and via CCK-A receptor mechanism which localization is unknown. Preliminary studies have indicated this later mechanism as being related to the growth performance of pigs. The planned studies will comprise a pharmacologic characterization and an immunohistologic localization of the components and messengers involved in the CCK-dependent neuro-hormonal pancreatic regulation using an appropriately catheterized pig model. Since the applied aim of the project is to correlate the growth of the pigs to the effectiveness of the pancreatic secretion and to the development of its regulatory mechanisms, the experiments will be performed on pigs having different growth and performance.

It is expected that the discussion will provide important applicable understanding of pancreatic function and its impact on pig growth and performance and also highlight the mechanism of the inter-organ regulatory pathways of the exocrine pancreatic function.
\end{abstract}

KEY WORDS: pig growth, regulatory mechanism, pancreas

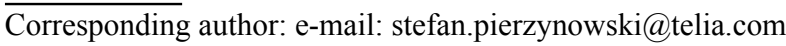




\section{FACTS}

The pancreas is the largest secretory gland of the body and it is located between the stomach and the duodenum in mammals. Its main exocrine function is to synthesize and release the enzymes, necessary for food digestion, from the acinar cells and produce bicarbonate in the ductal cells to neutralize the gastric acid. However, the pancreas has also an endocrine function, that of releasing hormones from the islets of Langerhans, e.g., insulin, the main hormone that regulates the carbohydrate, protein and lipid metabolism. The exocrine pancreatic function is regulated by the central nervous system via the vagus nerves, and by hormones. Two hormones, secretin and cholecystokinin (CCK), are considered to be the main gut hormones regulating the exocrine pancreas but there may be others as well. Secretin is released from enteroendocrine S-cells, located in the small bowel, and acid is the main stimulator of the bicarbonate secretion from the pancreatic ductal cells. CCK is released from I-cells and neurons in the duodenum and the jejunum, in the presence of lipids and proteins from ingested food. CCK together with impulses from the vagal-cholinergic pathway are the main regulators of the pancreatic secretion of the digestive enzymes.

Active CCK forms arise from pro-cholecystokinin, a protein giving rise to CCK peptides of various sizes from 4 to 58 amino acids. CCK-33 was the first CCK-peptide isolated and this was obtained from pig intestine. Later, CCK has been derived in other forms as well (Morisset et al., 2003). Two receptor subtypes have been found with different binding affinities for CCK, CCK-A with high affinity and CCK-B receptors with low affinity. The CCK receptors belong to the superfamily of G-protein-coupled receptors, sharing a similar molecular structure of seven transmembrane $\alpha$-helices with the N-terminal outside and the C-terminal inside the cell. When the CCK-receptor is activated, the intracellular $\mathrm{Ca}^{2+}$-concentration increases10-100 fold, resulting in exocytosis of cytoplasmatic stored granules and an increased enzyme secretion (Konturek et al., 2003). Several studies (Bourassa et al., 1999; Schweiger et al., 2000; Morriset et al., 2003) have shown a varying localization of CCK receptors in the pancreas and other tissues of different species. In rats, CCK-A receptors are present on pancreatic acinar cells, while pigs and humans do not express any $\mathrm{CCK}$ receptors on the pancreatic acinar cells. Both CCK-A and CCK-B receptors have been located on the pancreatic islet cells (Schweiger et al., 2000; Morriset et al., 2003).

The regulation of the pancreas in pigs, as studied in our lab (Evilevitch et al., 2002, 2004) appears to be highly specific and different from, e.g., rats. The pig pancreatic acinar cells do not possess any CCK-receptors (Schweiger et al., 2000; Morriset et al., 2003), and physiological doses of CCK given to the general circulation have failed to stimulate the pancreatic secretion (Cuber, 1989; Evilevitch Thesis). In spite of this finding it was proven that CCK is a main regulator of the exocrine pancreas in pigs. In experiments (Evilevitch et al., 
2004) where CCK was administered via the duodenal arterial circulation in doses reproducing peripheral postprandial levels, a strong stimulation of the pancreatic enzyme secretion was achieved. Studies with a specific CCK-B receptor blocker showed that the stimulation was mediated via CCK-B receptors. Studies with a blockade of CCK-A receptors (Evilevitch et al., 2002, 2004) clearly showed that there were no functioning CCK-A receptors in the duodenum, and that the CCK-A receptors responsible for the exocrine pancreatic stimulation using high, pharmacological doses of CCK are located elsewhere.

Several studies have shown that pancreatic insufficiency (PI) results in a reduced weight gain in different species. In animals, pancreatic duct ligation has been used as a method to demonstrate that a properly functioning pancreas is needed for an animal to obtain normal growth. In studies with PI-pigs (Imondi et al., 1972; Corring and Bourdon, 1977; Saloniemi et al., 1989) a reduction in daily weight gain of $25-100 \%$ was found. Supplementation of pancreatic enzymes to PIpigs has been shown to stimulate their growth (Saloniemi et al., 1989). Gregory et al. (1999) observed the same effect in PI-mini pigs. Preliminary studies performed by our group showed that pigs with a low growth rate responded weakly or not at all to CCK-A-receptor mediated stimulation of the exocrine pancreas, while fast growing piglets showed a strong exocrine pancreatic response after stimulation via either of the two CCK receptor-subtypes (Rengman, 2004). Moreover, studies by Botermans and Pierzynowski (2000) on weaned piglets and Pierzynowski et al. (2004) on suckling piglets showed a positive correlation between growth, feed conversion, pancreatic enzyme secretion, and CCK levels in the blood. These results implied that the function and regulation of the exocrine pancreas is closely connected to an efficient feed conversion and growth rate in piglets.

\section{HYPOTHESES}

Our previous studies suggest that the pancreatic enzyme secretion in pigs is regulated via a ("strong") entero-pancreatic reflex originating in the duodenum, with the CCK-B receptor being primarily involved (Evilevitch, 2004). However, the complete reflex arc is unknown. Direct entero-pancreatic neurons have recently been identified and possible candidates for terminal mediators/receptors on the pancreatic acinar cells are 5-HT, acetylcholine (via m1-, m3-receptors) or adrenalin, (via a1, a2, b2-receptors). The involvement of pancreatic ganglions with both classical and peptidergic neuromediators in this reflex is also possible. Moreover, the islets cells and their hormones are not excluded, especially since receptors for the above mentioned classical neuromediators are present on the islet cells.

In parallel, a pancreatic CCK-dependent reflex exists mediated via CCK-A receptors appearing to originate elsewhere than in the duodenum (Evilevitch 
et al., 2004). Although no CCK-A receptors have been found on the pancreatic acinar cells, a significant number of such receptors have been found on the pancreatic endocrine islet cells (Schweiger et al., 2001; Morisset et al., 2003). Thus, it is possible that endogenous CCK or exogenous CCK administered via the peripheral circulation in high amounts may activate CCK-A receptors on islet cells and stimulate the release of islet hormones, like, insulin and insulin-like growth factor (IGF) from B-cells, glucagons from A-cells or somatostatin from D-cells. Alternatively, CCK may stimulate pancreatic and visceral ganglionic neurons releasing adrenaline, acetylcholine or neuropeptide as mediators. High intra-pancreatic levels of these hormones and mediators may then act directly on the acinar cells, since the pancreatic blood flow from the pancreatic islets and ganglions must pass the acinar cells before entering the portal circulation (Lifson et al., 1980).

In addition these CCK-mediated reflexes appear to function in parallel but with some temporal difference. One may postulate that the CCK-B receptor-mediated entero(duodenal)-pancreatic reflex is related to the intestinal digestive phase, while the CCK-A receptor-dependent pancreatic reflex is coupled to the metabolic phase of the pancreatic regulation. After a primary function of stimulating the pancreatic enzyme secretion (in response to food stimulation), in the place of their origin, the islet hormones also regulate the metabolism - the utilization and deposition of the absorbed dietary components being the products of this enzymatic degradation. This appear to be an ideal example of the integration of digestive function and nutrient utilization with growth. In fact, our preliminary studies supported the possibility of this relation since pigs characterized by slow growth does not exhibit any activity of the long pancreatic CCK-A receptor dependent reflex and produce fewer pancreatic enzymes (Botermans et al., 1999; Rengman, 2004).

\section{OBJECTIVES FOR FUTURE STUDIES}

The aim of the future projects should be to highlight correlation to the growth of pigs to the effectiveness of exocrine pancreas function and to the development of the regulatory mechanism of exocrine pancreas.

In order to carry out this aim, it is necessary to study and clarify the components, pathways and messengers, of CCK receptors involved in the CCK-dependent regulatory pathway of exocrine pancreas in growing pigs.

It can be expected that the results of such studies will not only highlight the mechanism of inter-organ regulatory pathways of the exocrine pancreatic function, but also provide important applicable knowledge of pancreatic function and its impact on pig growth and performance. The studies will help us to identify the main CCK-dependent pathway regulating the exocrine 
pancreas in this animal, which can be a possible bottle neck in pig growth and performance.

We believe that in the future we can improve the function of this or these mechanisms and thus improve pig performance.

\section{REFERENCES}

Ahren B., 2000. Autonomic regulation of islet hormone secretion - implications for health and disease. Diabetologia 4, 393-410

Botermans J.A.M., Svendsen J., Svendsen L.S., Pierzynowski S.G., 1999. The exocrine pancreas in pig growth and performance. In: S.G. Pierzynowski, R. Zabielski (Editors). Biology of the Pancreas in Growing Animals. Elsevier, Amsterdam, pp. 395-408

Bourassa J., Lainé J., Kruse M.L., Gagnon M.C., Calvo E., Morisset J., 1999. Ontogeny and species differences in the pancreatic expression and localizaton of the $\mathrm{CCK}_{\mathrm{A}}$ receptors. Biochem. Biophys. Res. Commun. 260, 820-828

Corring T., Bourdon D., 1977. Exclusion of pancreatic exocrine secretion from intestine in the pig: existence of a digestive compensation. J. Nutr. 107, 1216-1221

Cuber J.C., Corring T., Levenez F., Bernard C., Chayvialle J.A., 1989. Effects of cholecystokinin octapeptide on the pancreatic exocrine secretion in the pig. Can. J. Physiol. Pharmacol. 67, 1391-1397

Evilevitch L., 2004. Regulation of the exocrine pancreas in growing pigs, with special emphasis on entero-pancreatic reflexes. PhD. Thesis, Department of Cell Organism Biology, Lund University (Sweden)

Evilevitch L., Weström B.R., Pierzyniowski S.G., 2003. CCK Regulates pancreatic enzyme secretion via short duodenal-pancreatic reflexes in pigs. Scand. J. Gastroenterol. 2, 201-206

Evilevitch L., Weström B.R., Pierzynowski S.G., 2004. The CCK2 receptor antagonist YF476 inhibits pancreatic enzyme secretion at a duodenal level in pigs. Scand. J. Gastroenterol. 39, 886-890

Georgsson L., Svendsen J., 2002. Degree of competition at feeding differentially affects behaviour and performance of group-housed growing-finishing pigs of different relative weights. J. Anim. Sci. 80, 376-383

Gregory P.C., Tabeling R., Kamphues J., 1999. Growth and digestion in pancreatic duct ligated pigs. Effect of enzyme supplementation. In: S.G. Pierzynowski, R. Zabielski (Editors). Biology of the Pancreas in Growing Animals. Elsevier, Amsterdam, pp. 381-394

Imondi A.R., Stradley R.P., Wolgemuth R., 1972. Enzyme replacement therapy in the pancreatic duct ligated swine. Proc. Soc. Exp. Biol. Med. 141, 1, 367-72

Kanno T., Ueda N., Saito A., 1978. Insulo-acinar axis: A possible role of insulin potentiating the effects of pancreozymin in the pancreatic acinar cells. In: T. Fujita (Editor). Endocrine Gut and Pancreas. Elsvier Scientific Publishing Company, Amsterdam, pp. 335-345

Kilea P., Zabielski R., Podgurniak P., Midura M., Barej W., Gregory P., Pierzynowski S.G., 1996. Cholecystokinin- 8 and vasoactive intestinal polypeptide stimulate exocrine pancreatic secretion via duodenally mediated mechanisms in the conscious pig. Exp. Physiol. 81, 375-384

Kirchgessner A., Liu M.T., 2000. Neurohormonal regulation of the pancreas. In: M. Singer, H.J. Krammer (Editors). Neurogastroenterology. From the Basics to the Clinics. Dordrecht, Kluwen, pp. 267-287

Konturek S.J., Zabielski R., Konturek J.W., Czarnecki J., 2003. Neuroendocrinology of the pancreas; role of brain-gut axis in pancreatic secretion. Eur. J. Pharmacol. 481, 1-14 
Lesniewska V., Gregard A., Weström B., Hedemann M.S., Laerke H.N., Kruszewska D., Pierzynowski S.G., 2001. The role of cholinergic and peptidergic pathways in the regulation of pancreatic exocrine function during postnatal development in pigs. Exp. Physiol. 86, 399-409

Lifson N., Kramlinger K.G., Mayrand R.R., Lender E.J., 1980. Blood flow to the rabbit pancreas with special reference to the islets of Langerhans. Gastroenterology 79, 66-73

Morisset J., Julien S., Lainé J., 2003. Localization of cholecystokinin receptor subtypes in the endocrine pancreas. J. Histochem. Cytochem. 51, 1501-1513

Pierzynowski S.G., Podgurniak P, Mikolajczyk M., Szczesny W., 1986. Insulin and the parasympathetic dependence of pancreatic juice secretion in healthy and alloxan diabetic sheep. Quart. J. Exp. Phys. 71, 401-407

Pierzynowski S.G., van den Borne J.J.G.C., Weström B.R., Botermans J.A.M., Woliński J., Valverde Piedra J.L., Svendsen J., Verstegen M.W.A., 2004. The Effect of milk replacer and sow milk on exocrine pancreatic secretion and the relations between milk intake, daily weight gain, exocrin pancreatic secretion, and blood parameters in the young chronically catheterised pig. J. Anim. Sci. (Submitted)

Pierzynowski S.G., Weström B.R., Svendsen J., Nilsson B., 1988. Pancreatic cannulation of young pigs for long-term study of exocrine pancreatic function. Can. J. Anim. Sci. 68, 953-959

Rådberg K., Botermans J., Weström B.R., Pierzynowski S.G., 1999. Depressive effects of anaesthesia or sedation on exocrine pancreatic function in pigs. Lab. Anim. Sci. 49, 662-664

Rengman S., 2004. The influence of CCK-33 and vagal innervation on the exocrine pancreas in growing pig. Master Thesis, Department of Cell Organism Biology, Lund University

Saloniemi H., Kalima T.V., Rahko T., 1989. Pancreatic enzyme supplementation in normal and exocrine pancreatic insufficient pigs. Acta Vet. Scand. 30, 367-370

Schweiger M., Erhard M.H., Amselgruber W.M., 2000. Cell-specific localization of the cholecystokininA receptor in the porcine pancreas. Anat. Histol. Embryol. 29, 357-61

Williams J.A., Goldfine I.D., 1985. The insulin-pancreatic acinar axis. Diabetes 34, 980-986

\section{STRESZCZENIE}

\section{Zależności miedzy wzrostem świń i mechanizmem regulującym trzustkę - fakty i hipotezy}

Celem opracowania jest określenie zależności miedzy zewnętrzną funkcją trzustki i wzrostem młodych świń. Do wyjaśnienia tych zagadnień niezbędne jest poznanie roli składników, dróg i przekaźników zaangażowanych w CCK-zależną neuro-hormonalną regulację zewnętrznej aktywności trzustki u rosnących świń. Mechanizmy te są w większości nieznane, a rola CCK jest kwestionowana, ponieważ nie ma receptorów CCK na komórkach pęcherzykowych produkujących enzym. Nasze dotychczasowe wyniki wskazują na istotną rolę CCK (przez CCK-B) w odruchu jelitowo-dwunastniczo-trzustkowym i poprzez mechanizm zależny od receptora CCK-A, którego lokalizacja nie jest znana. Badania wstępne wskazuja na ten ostatni mechanizm jako związany ze wzrostem świń. Prowadzone doświadczenia mają na celu porównanie farmakologicznej charakterystyki i immunologicznej lokalizacji składników i neuroprzekaźników włączonych w zależny od CCK mechanizm neurohormonalnej regulacji trzustki przy użyciu modelu świni zaopatrzonej w katetery. Celem badań jest znalezienie zależności między wzrostem świń a efektywnością sekrecji trzustkowej i rozwojem jej mechanizmów regulujących. Doświadczenia będą przeprowadzone na świniach o różnym tempie wzrostu i produkcyjności.

Oczekuje się, że dyskusja tego problemu przyniesie zrozumienie istotnych funkcji trzustki, ich wpływu na wzrost i produkcyjność świń, wyjaśni powiązania miedzy poszczególnymi organami, a także znaczenie zewnętrznej funkcji trzustki. 